\title{
Chemical Composition and Antibacterial Effect of Plantago Major Extract on Periodontal Pathogens
}

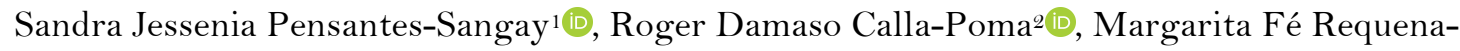 \\ Mendizabal'º, María Isabel Alvino-Vales $^{3}{ }^{\circledR}$, Pablo Alejandro Millones-Gómez ${ }^{4}$
}

${ }^{1}$ Department of Dentistry, Universidad Cesar Vallejo, Trujillo, Peru.

2Department of Oral Rehabilitation, Faculty of Dentistry, Universidad Nacional Mayor de San Marcos, Lima, Peru.

${ }^{3}$ Department of Dentistry, Universidad Privada San Juan Bautista, Lima, Peru.

${ }^{4}$ Posgraduate School, Universidad Norbert Wiener, Lima, Peru.

Author to whom correspondence should be addressed: Pablo A. Millones-Gómez, Posgraduate School, Universidad Norbert Wiener, Lima, Peru. Phone: +51 944908425. E-mail: pablodent@hotmail.com.

Academic Editors: Alessandro Leite Cavalcanti and Wilton Wilney Nascimento Padilha

Received: 08 February 2020 / Accepted: 13 April 2020 / Published: 04 June 2020

How to cite this article: Pensantes-Sangay SJ, Calla-Poma RD, Requena-Mendizabal MF, Alvino-Vales MI, MillonesGómez PA. Chemical composition and antibacterial effect of Plantago Major extract on periodontal pathogens. Pesqui Bras Odontopediatria Clín Integr. 2020; 20:e0012. https://doi.org/10.1590/pboci.2020.100

\begin{abstract}
Objective: To determine the in vitro antibacterial effect of different concentrations of the ethanol extract of Plantago major (plantain) on Porphyromonas gingivalis and Fusobacterium nucleatum. Material and Methods: Bacterial susceptibility tests were used in conjunction with the agar diffusion test and the minimum inhibitory concentration (MIC) test using the broth macrodilution technique. Results: Different concentrations of ethanol extract $(25 \%, 50 \%, 75 \%$ and $100 \%)$ dissolved in $70 \%$ ethanol were used, with a positive control $(0.12 \%$ chlorhexidine $+0.05 \%$ cetyl-pyridinium chloride) and a negative control $(70 \%$ alcohol). The extracts at $75 \%$ and $100 \%$ showed inhibition halos against both strains studied. With $0.12 \%$ chlorhexidine $+0.05 \%$ cetyl-pyridinium chloride, inhibition halos averaged $14.9 \mathrm{~mm}$, in contrast to $70^{\circ}$ alcohol, where no bacterial inhibition was observed. The MIC was $50 \%$ for both species. Conclusion: The ethanol extract of Plantago major presents an in vitro antibacterial effect on Porphyromonas gingivalis, they may have potential applications in food and pharmaceutical products.

Keywords: Plants, Medicinal; Periodontics; Gram-Negative Bacteria; Microbiology.
\end{abstract}




\section{Introduction}

Periodontal disease is an inflammatory, infectious and multifactorial disease in which the normal balance between the microbial biofilm and host response is altered [1,2]. Among periodontal diseases, periodontitis deserves special attention because it includes all the processes that compromise the structure of supporting tissue and thus considered one of the main causes of tooth loss in adults [3-5] and is categorized by the World Health Organization as the eleventh most prevalent disease in the world [6].

Two of the most important periodontal pathogens, for their high virulence and association with onset, progression and severity of disease, are Fusobacterium nucleatum and Porphyromonas gingivalis [7-11]. These species present several virulence factors: a capsule made of polysaccharides, important for evading the immune system; an endotoxin in their outer membrane, which participates in interrupting the immune homeostasis of the host, causing inflammation and destruction of the connective tissue and reabsorption of the alveolar bone; and external membrane vesicles, with internal enzymes that damage periodontal cells and neutrophils [12-14]. In fact, the aetiology of periodontal diseases is currently conceived as a dysbiosis between bacteria present in dental biofilms and the response of the host against this bacterial threat, which is responsible for the clinical expression of gingivitis or periodontitis $[11,14,15]$.

For these reasons, dental care is a component of great importance in the treatment of periodontitis, with the removal of bacterial biofilm being essential for remission of this disease [9,16], with certain local agents that act as adjuvants of periodontal therapy, such as chlorhexidine, currently considered the gold standard. However, reports of its adverse effects [16-20] have redirected research to the discovery of new agents, emphasizing natural agents because they have fewer side effects [21].

One of these agents is Plantago major, commonly known as "greater plantain", "common plantain" or "broadleaf plantain"; it is a perennial herbaceous plant with unbranched underground stems and is widely marketed for its anti-inflammatory, antibacterial, astringent, antihemorrhagic and wound healing properties [22-24]. Plantago major belongs to the family Plantaginaceae. Originally from Europe and Asia, it is distributed throughout most of Europe, North Africa, Western Asia, North America and Latin America. It grows in temperate and cold climates, is easy to find, is not cultivated and is considered a weed. Its height varies between 15 and $30 \mathrm{~cm}$, its life cycle is between 6 and 7 months, and its flowering occurs between May and October [22-24]. It has several active ingredients, such as mucilage, pectin, flavonoids, tannins, an iridoid chromogenic glycoside called aucubin, catalpol, acteroside, plantamajoside, baicalein, allantoin, hispidulin, ursolic acid and oleanolic acid, salicylic acid, and mineral salts of potassium and zinc [24,25].

Previous authors showed that the antimicrobial properties of Plantago major against Staphylococcus aureus [26], Helicobacter pylori [27], and antibacterial activity against Streptococcus mutans, Lactobacillus acidophilus, Actinomyces viscosus, Prevotella melaninogenicus and Fusobacterium nucleatum [28]; likewise, another research also established the antibacterial effect of Plantago major against Fusobacterium nucleatum [29]. Furthermore, some authors demonstrated the synergistic inhibitory effect of chamomile extract (Matricaria chamomilla) and plantain extract (Plantago major 1.) on P. gingivalis [30].

There are multiple benefits of Plantago major; however, there have not been many studies reporting its antibacterial effect against Porphyromonas gingivalis, which motivated the present study, the objective of which was to determine the in vitro antibacterial effect of different concentrations of the ethanol extract of Plantago major (plantain) on Porphyromonas gingivalis and Fusobacterium nucleatum.

\section{Material and Methods}


Protocol for Obtaining the Extract

Three kilogrammes of fresh Plantago major leaves (Figures $1 \mathrm{~A}$ and $1 \mathrm{~B}$ ) were collected from the village of Huacariz, district of Cajamarca, at 2750 meters above sea level. A specimen of the plant was taken to Herbarium Truxillensis of the National University of Trujillo for taxonomic identification and verification. The rest of the plant material was transported to the Pharmacognosy Laboratory of the same university, where leaves that were in good condition were selected. Then, the plant material was washed with distilled water, followed by disinfection with $0.5 \%$ sodium hypochlorite.

Subsequently, the leaves were rinsed with sterile distilled water to remove the hypochlorite residue and then placed on Kraft paper and dried in a forced-air circulation oven at $40^{\circ} \mathrm{C}$. After the leaves were dried, they were ground with a mortar and pestle until a coarse powder was obtained and then passed through a set of sieves to homogenize the particle size (Figures $1 \mathrm{C}$ and 1D). For the preparation of the ethanol extract, $100 \mathrm{~g}$ of dried, pulverized and sieved leaves was placed in a 2-litre glass flask, and then $500 \mathrm{~mL}$ of $70^{\circ}$ ethanol was added, thoroughly mixed and refluxed for 4 hours. After this time, the ethanol extract was vacuum-filtered through Whatman filter paper No. 1. Subsequently, the ethanol extract was concentrated in a rotavapor until a soft extract was obtained (Figure $1 \mathrm{E}$ ). Then, the extract was dried in a forced-air circulation oven at $40{ }^{\circ} \mathrm{C}$ until dry extract was obtained. From the dry extract, $25 \%(250 \mathrm{mg} / \mathrm{mL}), 50 \%(500 \mathrm{mg} / \mathrm{mL}), 75 \%(750$ $\mathrm{mg} / \mathrm{mL})$ and $100 \%(1000 \mathrm{mg} / \mathrm{mL})$ extract samples dissolved in $70 \%$ ethanol were prepared. Finally, the ethanol extracts were stored in amber-coloured glass bottles and refrigerated at 4 to $8^{\circ} \mathrm{C}$ until further use (Figures $1 \mathrm{G}$ and $1 \mathrm{H}$ ).
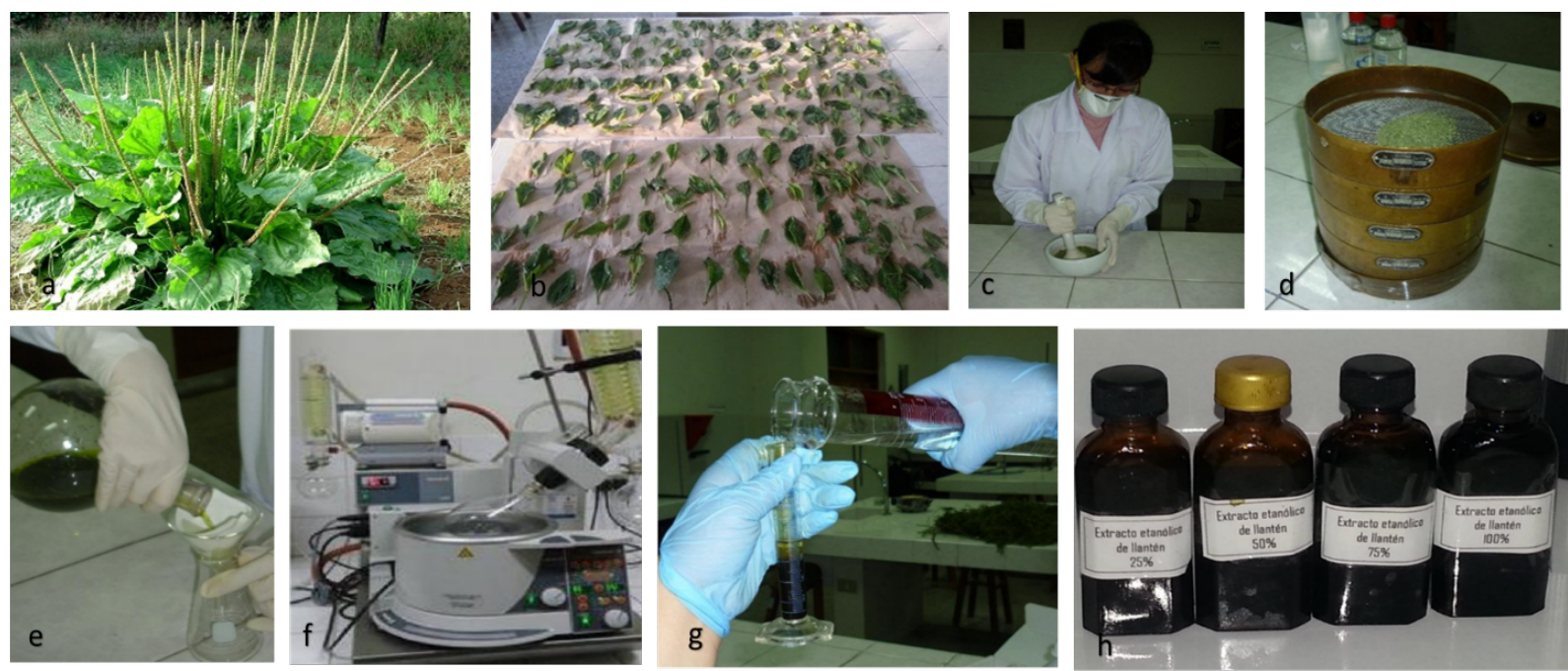

Figure 1. Extract preparation: A. Plantago major; B. Dried in a forced-air circulation; C. Ground with a mortar and pestle; D. Homogenized particle size; E. $70^{\circ}$ Ethanol added; F. Soft extract by rotavapor; G. and H. Extract samples.

Obtaining the Strains

The strains Porphyromonas gingivalis (ATCC 33277) and Fusobacterium nucleatum (ATCC 10953) were obtained from the Belomed Laboratory of the city of Lima, Peru, which were imported from the Thermo Fisher Scientific Inc. (Waltham, Massachusetts, USA).

Preparation of Culture Media and Bacterial Strains

Preparation of Brain Heart Infusion (BHI) Broth 
The BHI broth was prepared from dehydrated commercial medium following the manufacturer's instructions. A total of $2.8 \mathrm{~mL}$ was poured into $15 \times 100 \mathrm{~mm}$ test tubes. Immediately after autoclaving at $121^{\circ} \mathrm{C}$ at 15 pounds of pressure, the medium cooled for 15 minutes.

\section{Preparation of Enriched Schaedler Agar}

Schaedler agar enriched from dehydrated commercial medium was prepared following the manufacturer's instructions. Immediately after autoclaving $\left(121^{\circ} \mathrm{C}, 15\right.$ pounds of pressure, for 15 minutes), the agar cooled in a water bath at $45-50^{\circ} \mathrm{C}$. Sterile defibrinated sheep blood was added in a proportion of $5 \%+0.1$ $\mathrm{mL}$ of vitamin $\mathrm{K} 1$. The fresh and warm preparation was poured into a level flat-bottomed glass Petri dish to provide a uniform bottom approximately $4 \mathrm{~mm}$ thick; this corresponded to $25-30 \mathrm{~mL}$ per $100 \mathrm{~mm}$-diameter Petri dish. The agar medium was cooled to room temperature. A representative sample of each lot of plates was examined for sterilization by incubation at $36 \pm 1^{\circ} \mathrm{C}$ for 24 hours or more. The $\mathrm{pH}$ was checked when the medium was prepared. The agar presented a $\mathrm{pH}$ of 7.2 after gelling at room temperature.

\section{Reactivation of Strains}

Lyophilized strains were rehydrated by breaking the ampoule contained in the original rubber tube. The strains were incubated for 15 minutes at $36^{\circ} \mathrm{C}+1{ }^{\circ} \mathrm{C}$ and then seeded using the streak-plating method on Schaedler agar enriched with defibrinated sheep blood (5\%) + vitamin K1 and incubated under anaerobic conditions (Gas Pak jar) at $36^{\circ} \mathrm{C}+1{ }^{\circ} \mathrm{C}$ for 7 days (Figure $\left.2 \mathrm{~A}\right)$.

Creation of an Anaerobic Environment

An anaerobic environment, created by an anaerobiosis generator (AnaeroGen, Thermo Fisher Scientific Inc., Waltham, Massachusetts, USA) was placed inside the Gas Pak jar and closed tightly, achieving an anaerobic environment after 30 minutes.

In Vitro Susceptibility to Antibacterials

Standardization of the Inoculum

For P. gingivalis, 3 to 5 colonies were selected and suspended in $4 \mathrm{~mL}$ of BHI broth and then incubated between 2 to 5 hours, obtaining a final turbidity of 0.5 on the McFarland scale (Figure $2 \mathrm{~B}$ ). For F. nucleatum, soy trypticase agar supplemented with $5 \%$ sheep blood, hemin $(5 \mathrm{mg} / \mathrm{L})$ and menadione $(1 \mathrm{mg} / \mathrm{L})$ were used for 24 hours to verify sterility. The two bacteria were cultured under anaerobic conditions $(10 \% \mathrm{H} 2,10 \% \mathrm{CO} 2$ and $\mathrm{N}_{2}$ in equilibrium) at $37^{\circ} \mathrm{C}$ for 24 hours and then brought to 0.5 on the McFarland scale (Figure $2 \mathrm{C}$ ).

Preparation and Impregnation of the Discs

Twenty microlitres of these preparations or concentrations was added to Whatman No. 3 filter paper discs (Oxford; $6 \mathrm{~mm}$ in diameter) with the aid of a micropipette (Boeco Germany, Hamburg, Germany), allowing them to rest for 10 minutes until the preparation was completely absorbed.

Evaluation of Antibacterial Activity

Disc Diffusion Test in Agar

The Kirby-Bauer-based antibiogram method is recommended by CLSI for the determination of bacterial sensitivity to antibacterial agents [31]. In a period of 15 minutes after adjusting the turbidity of the 
inoculum suspension of each previously standardized strain, a sterile Dacron swab was immersed and rotated several times and pressed firmly against the inner wall of the tube above the liquid level, thereby removing the excess inoculum. The surface of the Petri dishes containing enriched Schaedler agar (4 mm thick) were inoculated by swabbing the entire surface in three different directions, rotating the plate approximately $60^{\circ}$ each time. Then, the swab was passed over the edges of the agar. This was performed for 12 repetitions. Immediately afterwards, discs previously impregnated with the study solutions $(25 \% ; 50 \% ; 75 \%$ and $100 \%)$ of the ethanol extract of P. major were placed, including one disc containing $0.12 \%$ chlorhexidine gluconate + $0.05 \%$ cetyl-pyridinium chloride (positive control) and another containing $70^{\circ}$ ethyl alcohol (negative control), with all solutions distributed equidistantly on the agar. The plates were placed inverted into an anaerobic environment (Gas Pak jar) and incubated (Memmert GmbH + Co. KG, Schwabach, Germany) at $35^{\circ} \mathrm{C}$ for 7 days (Figure 2D).
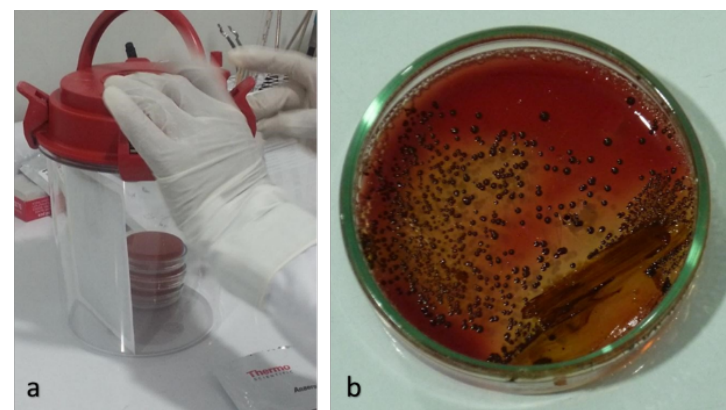

Figure 2. A. Gas Pak jar; B. Plantago major / diffusion test in agar.
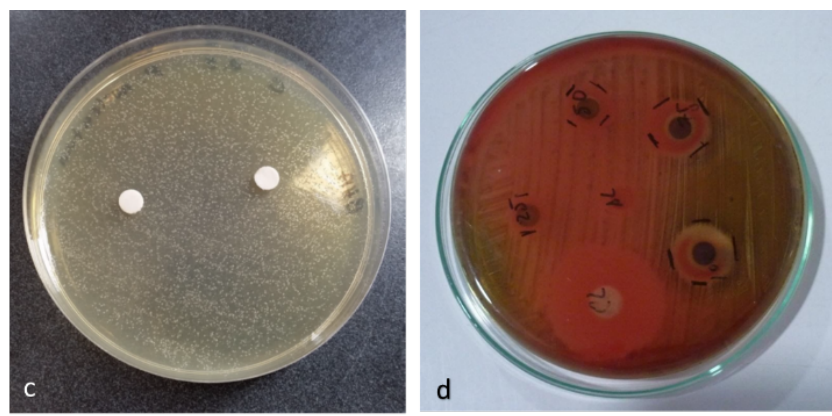

P. gingivalis strains; C. F. nucleatum strains; D. Disc

Minimal Inhibitory Concentration (MIC) Test

According to document M11 of the CLSI, which describes the specific standards for analysing anaerobes, MIC macrodilution in broth was used. a) The inoculum was prepared following the same guidelines as previously described. b) For the evaluation of antibacterial activity, a total of 13 sterile test tubes $(13 \times 100$ $\mathrm{mm}$ ) were prepared for each strain. To determine the MIC, several dilutions of the ethanol extract were performed $(25 \%, 30 \%, 35 \%, 40 \%, 45 \%, 50 \%, 55 \%, 75 \%$ and $100 \%)$. To each of the test tubes (labelled 1-9), 800 $\mu \mathrm{L}$ of pure bacteria culture $+200 \mu \mathrm{L}$ of the ethanol extract of P. major were added according to the respective concentration (experimental group). To tube No. 10 was added $800 \mu \mathrm{L}$ of pure bacteria culture $+200 \mu \mathrm{L}$ of $0.12 \%$ chlorhexidine gluconate (positive control), to tube No. 11 was added $800 \mu \mathrm{L}$ of pure strain culture +200 $\mu \mathrm{L}$ of $70^{\circ}$ alcohol (negative control), to tube No. 12 was added $1000 \mu \mathrm{L}$ of culture medium (sterility control) and to tube No. 13 was added $800 \mu \mathrm{L}$ of sterile culture broth $+200 \mu \mathrm{L}$ of pure strain culture (Bacterial growth control). The entire procedure included 12 repetitions. Then, all test tubes were placed under anaerobic conditions (Gas Pak jar) and incubated (Memmert GmbH + Co. KG, Schwabach, Germany) at $35{ }^{\circ} \mathrm{C}$ for 7 days.

Reading and Interpretation

Bacterial growth was observed in each of the tubes, and the minimum concentration of the extract capable of inhibiting this growth was determined. Growth was considered present when the broth was cloudy and absent when the broth remained clear. 
For the bacterial susceptibility test, a PCE Vernier calliper was used to measure the diameter of the bacterial inhibition halos. For the MIC, turbidity was visually inspected by holding the tubes against a white background with horizontal black lines for contrast. The data were recorded in a data collection form.

\section{Statistical Analysis}

IBM SPSS Statistics for Windows Software, version 22 (IBM Corp., Armonk, NY, USA) was used. One-way frequency tables were constructed with their absolute values. The mean and standard deviation were calculated with their corresponding graphs. To determine the antibacterial effect of $P$. major on both strains, analysis of variance corresponding to a completely randomized design was performed. Then, Duncan's multiple range test and Tukey's test were applied, with a significance level of $5 \%(\mathrm{p} \leq 0.05)$.

\section{Results}

The ethanol extract of Plantago major at 25\% presented an average halo inhibition diameter of $0.0 \mathrm{~mm}$ against $P$. gingivalis and $F$. nucleatum; at 50\%, the average halo inhibition diameter was $1.7 \mathrm{~mm}$ and $0.0 \mathrm{~mm}$, respectively, at $75 \%$, the average halo inhibition diameter was $5.2 \mathrm{~mm}$ and $0.0 \mathrm{~mm}$, respectively, and at $100 \%$, the average halo inhibition diameter was $6.2 \mathrm{~mm}$ and $0.0 \mathrm{~mm}$, respectively, indicating that the bacterial sensitivity was zero at $25 \%$ and $50 \%$, with the resistance breakpoint at $75 \%$ and $100 \%$. Regarding the positive control, a mean inhibition halo of $14.9 \mathrm{~mm}$ was observed; both strains were extremely sensitive to this product, in contrast to the negative control, for which the sensitivity was zero (Table 1).

Table 1. Average size of inhibition halos (in $\mathrm{mm}$ ) according to study group.

\begin{tabular}{lccccc}
\multicolumn{1}{c}{ Study Group } & \multicolumn{2}{c}{$\boldsymbol{P}$. gingivalis } & \multicolumn{2}{c}{ F. nucleatum } \\
Ethanol extract of Plantago major 25\% & $\mathrm{N}$ & Mean & $\mathrm{N}$ & Mean & SD \\
\hline Ethanol extract of Plantago major 50\% & 12 & 0.0 & 12 & 0.0 & 0.10 \\
Ethanol extract of Plantago major $75 \%$ & 12 & 1.7 & 12 & 0.0 & 0.69 \\
Ethanol extract of Plantago major $100 \%$ & 12 & 5.2 & 12 & 0.0 & 0.74 \\
Positive Control & 12 & 6.2 & 12 & 0.0 & 0.93 \\
Negative Control & 12 & 14.9 & 12 & 14.9 & 0.30 \\
\hline
\end{tabular}

Positive Control: 0.12\% Chlorhexidine + 0.05\% Cetyl-pyridinium Chloride; Negative Control: Alcohol 70\%.

Tukey's multiple comparisons test showed a statistically significant difference between all groups, except between the $25 \%$ ethanol extract of $P$. major and that of $70^{\circ}$ alcohol (Table 2 ).

Table 2. Multiple comparisons tests.

\begin{tabular}{lcccccc}
\multicolumn{1}{c}{ Study Group } & $\mathbf{2 5 \%}$ & $\mathbf{5 0 \%}$ & $\mathbf{7 5 \%}$ & $\mathbf{1 0 0 \%}$ & PC & NC \\
\hline Ethanol extract of Plantago major 25\% & - & 0.007 & 0.000 & 0.000 & 0.000 & 1.000 \\
Ethanol extract of Plantago major 50\% & 0.007 & - & 0.000 & 0.000 & 0.000 & 0.005 \\
Ethanol extract of Plantago major 75\% & 0.000 & 0.000 & - & 0.000 & 0.000 & 0.000 \\
Ethanol extract of Plantago major $100 \%$ & 0.000 & 0.000 & 0.000 & - & 0.000 & 0.000 \\
Positive Control & 0.000 & 0.000 & 0.000 & 0.000 & - & 0.000 \\
Negative Control & 1.000 & 0.005 & 0.000 & 0.000 & 0.000 & - \\
\hline
\end{tabular}

Tukey's test; Positive Control: 0.12\% Chlorhexidine + 0.05\% Cetyl-pyridinium Chloride; Negative Control: Alcohol 70\%.

In reference to the MIC, the results were similar for both species. Of the 12 test tubes with $50 \%$ ethanol extract, ten (83\%) did not show bacterial growth; likewise, no growth was evidenced in any of the tubes with higher concentrations of extract, with the MIC corresponding to $50 \%$ (Table 3 ). 
Table 3. Minimum inhibitory concentration of the ethanol extract of Plantago major (plantain) against Porphyromonas gingivalis.

\begin{tabular}{lcc}
\hline Concentration of the Ethanol Extract & N & \%Growth \\
\hline $25 \%$ & 12 & 100 \\
$30 \%$ & 12 & 100 \\
$35 \%$ & 12 & 100 \\
$40 \%$ & 12 & 100 \\
$45 \%$ & 12 & 100 \\
$50 \%$ & 2 & 17 \\
$75 \%$ & 0 & 0 \\
$100 \%$ & 0 & 0 \\
Positive Control & 0 & 0 \\
Negative Control & 0 & 0 \\
Control for Sterility & 0 & 0 \\
Control for Culture Purity & 12 & 100 \\
\hline Positive Control: 0.12\% Chlorhexidine + 0.05\% Cetyl-pyridinium Chloride; Negative Control: Alcohol 70\%.
\end{tabular}

Table 4. Phytochemical composition of Plantago major.

\begin{tabular}{llc}
\hline Phytochemical Composition & \multicolumn{1}{c}{ Chemical Reagent } & Outcomes \\
\hline Catechins & $\mathrm{Na}_{2} \mathrm{CO}_{3}+\mathrm{Luz}$ UV & - \\
Lactones & Baljet & - \\
Triterpenes and Steroids & Liebermann - Burchard & + \\
Quinones & Bornträger & - \\
Cardiotonic Glycosides & Kedde & - \\
Phenolic Compounds & Cloruro Férrico & +++ \\
Flavonoids & Shinoda & ++ \\
Anthocyanidin & Antocianidina & + \\
Coumarins & Luz UV & + \\
Saponins & Espuma & + \\
Alkaloids & Dragendorff & + \\
& Mayer & + \\
Tannins & Wagner & + \\
\hline Positive Outcomes: +; Negatives Outcomes: -; Intensity: +Low; ++Moderate; +++High. & +
\end{tabular}

\section{Discussion}

The increasing number of cases of periodontal disease and the current trend towards the use of natural products as treatment for various conditions have increasingly centred on finding new natural phytotherapybased therapeutic alternatives to supplement treatment of this pathology.

One of these resources is Plantago major, commonly known as plantain, whose medicinal properties have been widely studied in various research studies, with little known about its antibacterial activity against Porphyromonas gingivalis and Fusobacterium nucleatum.

According to the halo measurements, the bacterial susceptibility test showed inhibition for all concentrations of Plantago major extract. There was a statistically significant difference between all groups, with greater inhibition at higher concentrations. However, based on Duraffourd's scale, only $75 \%$ and $100 \%$ exhibited sensitivity according to the inhibition halo breakpoints against both strains studied, demonstrating the antibacterial effect of Plantago major against $P$. gingivalis.

These results were similar to those described by other authors [30], who used the pure extract, finding a breakpoint with an average inhibition halo diameter of $12.47 \mathrm{~mm}$ against the same bacteria. However, in both studies, the diameters were smaller than those obtained with the respective positive controls; in our 
study, the inhibition halo diameter was $24.9 \mathrm{~mm}$ with $0.12 \%$ chlorhexidine $+0.05 \%$ cetyl-pyridinium chloride (Perio $\cdot$ Aid $^{\circledR}$ O.12 Intensive Care), and, according to previous findings, the diameter was $17.5 \mathrm{~mm}$ with $0.12 \%$ chlorhexidine only [30], suggesting that the combination of both products triggers the antibacterial effect of chlorhexidine, which continues to be the gold standard. However, the active principles of Plantago major deserve special attention as they explain the antibacterial behaviour of this product, considering, furthermore, that the presence of $70 \%$ alcohol as a dilution medium of the pure extract did not trigger its antibacterial activity, as evidenced in the sensitivity test when contrasting with the negative control, for which the same substance was used and there was $0 \mathrm{~mm}$ of bacterial inhibition.

Among the active principles in Plantago major are mucilages, pectins, flavonoids, tannins, and glycosides such as aucubin and catalpol, both in the leaves, flowers and stems. Aucubigenin, derived from aucubin, is an active principle of greater relevance because in its process of catabolism, by hydrolysis, it forms a dialdehyde that acts as a bactericide, denaturing the proteins of certain microorganisms. It also has various flavonoids, of which acteoside and plantamajoside have antibacterial properties. Despite knowledge of the different active principles of Plantago major, a more detailed and individual analysis is required to determine the main metabolite that confers the antibacterial property against both strains in the present study, which would guide future research.

In determining the MIC, it was found that at $50 \%, 83 \%$ of the test tubes did not exhibit bacterial growth; likewise, there was no evidence of growth in any of the tubes with higher concentrations of extract; therefore, the MIC corresponded to 50\%. The method used was broth microdilution.

This method is one of the most used and practical. In our study, one limitation was that the ethanol extract of Plantago major was greenish, i.e., the characteristic colour of the leaves of the plant; therefore, determining turbidity was more complicated. However, the use of a white background with horizontal black contrasting lines facilitated visual inspection. In addition, no bacterial growth was observed in the negative control with $70 \%$ alcohol, showing even greater clarity compared to the positive control with $0.12 \%$ chlorhexidine plus $0.05 \%$ cetyl-pyridinium chloride, maintaining this result in all replicates because $70 \%$ alcohol could show better antibacterial behaviour in a liquid dilution medium.

The results obtained in the present study demonstrate the antibacterial properties of Plantago major at high concentrations against $P$. gingivalis; however, they encourage further research on the medicinal properties as well as the possible toxicity of Plantago major in order to be used in clinical trials, in the future, in different presentations, such as coadjuvant therapy for periodontal treatment.

\section{Conclusion}

The ethanol extract of Plantago major (plantain) had an in vitro antibacterial effect against $P$. gingivalis, with a sensitivity of $75 \%$ and $100 \%$ and a MIC at $50 \%$.

\section{Authors' Contributions}

\begin{tabular}{|c|c|c|}
\hline SJPS & (iD) $0000-0002-3841-2735$ & Validation, Investigation and Writing - Original Draft Preparation. \\
\hline $\mathrm{RDCP}$ & (iD) $0000-0002-5128-212 \mathrm{X}$ & Conceptualization, Methodology, Formal Analysis and Data Curation. \\
\hline MFRM & (iD) $0000-0002-6113-1990$ & Conceptualization, Methodology, Formal Analysis and Data Curation. \\
\hline MIAV & (iD) 0000-0001-9014-4005 & Conceptualization, Methodology, Formal Analysis and Data Curation. \\
\hline PAMG & (iD) $0000-0002-7105-0940$ & $\begin{array}{l}\text { Validation, Investigation, Writing - Original Draft Preparation and Writing - } \\
\text { Review and Editing. }\end{array}$ \\
\hline
\end{tabular}




\section{Financial Support}

None.

\section{Conflict of Interest}

The authors declare no conflicts of interest.

\section{References}

[1] Lindhe J, Lang N, Karring T. Periodontología Clínica e Implantología Odontológica. Buenos Aires: Editorial Medica Panamericana; 2009. [In Spanish]

[2] Millones-Gómez P, Aguilar AA. Efficacy of azithromycin associated with scaling and root planing in chronic periodontitis. Rev Clín Periodoncia Implantol Rehabil Oral 2017; 10(1) 33-7.

[3] Ong G. Periodontal disease and tooth loss. Int Dent J 1998; 48(3 Suppl 1):233-8.

https://doi.org/10.1111/j.1875-595x.1998.tbo0711.x

[4] Adom MB, Taher M, Mutalabisin MF, Amri MS, Kudos MBA, Sulaiman MWAW, et al. Chemical constituents and medical benefits of Plantago major. Biomed Pharmacother 2017; 96:348-60. https://doi.org/10.1016/j.biopha.2017.09.152

[5] Millones-Gómez PAA, Bacilio-Amaranto RE, Torres DM, Cortavarría PS, Orocollo YC, Choque JSC, et al. Identification and localization of proteins associated with the formation of Streptococcus gordonii and Fusobacterium nucleatum biofilms. Available from: https://www.researchsquare.com/article/rs-11967/v1. [Accessed on January 20, 2020]. https://doi.org/10.21203/rs.2.21373/v1

[6] Velasco-Lezama R, Tapia-Aguilar R, Román-Ramos R, Vega-Avila E, Pérez-Gutiérrez MS. Effect of Plantago major on cell proliferation in vitro. J Ethnopharmacol 2006; 103(1):36-42. https://doi.org/10.1016/j.jep.2005.05.050

[7] Bascones A, Caballeros A. Actinobacillus actinomycetemcomitans y Porphyromonas gingivales como principales patógenos periodontales. Av Periodoncia Implantol Oral 2000; 12(2):69-75. [In Spanish]

[8] Socransky SSS, Haffajee AD, Cugini MA, Smith C, Kent Jr RL. Microbial complexes in subgingival plaque. J Clin Periodontol 1998; 25(2):134-44. https://doi.org/10.1111/j.1600-051x.1998.tb02419.x

[9] Escudero-Castaño N, Perea-García M, Bascones-Martínez A. Revisión de la periodontitis crónica: evolución y su aplicación clínica. Av Periodoncia Implantol Oral 2008; 20(1):27-37. [In Spanish ]

[10] Reddy PRT, Vandana KV, Prakash S. Antibacterial and anti-inflammatory properties of Plantago ovata Forssk. leaves and seeds against periodontal pathogens: an in vitro study. Ayu 2018; 39(4):226-9. https://doi.org/10.4103/ayu.AYU_176_16

[11] Ramos DP, Moromi HN, Martínez EC. Porphyromonas gingivalis: patógeno predominante en la periodontitis crónica. Odontol Sanmarquina 2011; 14(1):34-8.

[12] Lamont RJ, Jenkinson HF. Life below the gum line: pathogenic mechanisms of Porphyromonas gingivalis. Microbiol Mol Biol Rev 1998; 62(4):1244-63.

[13] Yilmaz Ö. The chronicles of Porphyromonas gingivalis: the microbium, the human oral epithelium and their interplay. Microbiol 2008; 154(10):2897-2903.

[14] Brunner J, Scheres N, El Idrissi NB, Deng DM, Laine ML, van Winkelhoff AJ, et al. The capsule of Porphyromonas gingivalis reduces the immune response of human gingival fibroblasts. BMC Microbiol 2010; 10:5. https://doi.org/10.1186/1471-2180-10-5

[15] Grenier D, Bertrand J, Mayrand D. Porphyromonas gingivalis outer membrane vesicles promote bacterial resistance to chlorhexidine. Oral Microbiol Immunol 1995; 10(5):3 19-20. https://doi.org/10.1111/j.1399-302x.1995.tbo0161.x

[16] Becerra TB, Calla-poma RD, Requena-mendizabal MF, Millones-Gómez PA. Antibacterial effect of Peruvian propolis collected during different seasons on the growth of streptococcus mutans. Open Denti J 2019; 13:2019:327-31. https://doi.org/10.2174/1874210601913010327

[17] Saavedra SLA, Herrera-Plasencia P, Enoki-Miñano E, Ruiz-Barrueto M, Gómez PAM. Efecto antibacteriano in vitro del extracto etanólico de Prosopis pallida sobre Enterococcus faecalis ATCC 29212. Rev Cubana Med Trop 2018; 70(2):1-12. [In Spanish]

[18] Rodriguez-Perez JL, Millones-Gomez PA. Antibacterial effect of Annona muricata L. leaves on Streptococcus mutans ATCC 25175 Strains. J Clin Diag Res 2019; 13(10):ZC13-ZC16. https://doi.org/10.7860/JCDR/2019/42089.13196

[19] Sofowora A, Ogunbodede E, Onayade A. The role and place of medicinal plants in the strategies for disease Prevention. Afr J Tradit Complement Altern Med 2013; 10(5):210-29.

[20] Millones-Gómez P, Huamaní-Muñoz W. Efectividad de la antibioticoterapia en la reducción de la frecuencia de alveolitis seca postexodoncia simple. Ensayo clínico aleatorizado de grupos en paralelo, controlado y ciego simple. Rev Esp Cirug Oral y Maxilofac 2016; 38(4):181-7. https://doi.org/10.1016/j.maxilo.2014.04.004 [In Spanish] 
[21] Millones-Gómez P, Alberto AA. Eficacia de la azitromicina asociada al RAR en periodontitis crónica: ensayo clínico, aleatorizado, controlado y triple ciego en grupos en paralelo. Rev Esp Cirug Oral y Maxilofac 2018; 40(3):129-34. https://doi.org/10.1016/j.maxilo.2017.08.001

[22] Amaranto REB, Millones Gómez PA. Analgesic effectiveness of lysine clonixinate associated with paracetamol in the postoperative treatment of exodontias. Rev Cien Salud 2019; 17(2):321-33. https://doi.org/10.12804/revistas.urosario.edu.co/revsalud/a.7943

[23] Rodríguez Y, Vera L, Moreno K, Montilla J, Guevara C, González R. Conocimiento sobre el uso del Plantago major como terapia alternativa en lesiones inflamatorias bucales. Rev Venez Invest Odont 2014; 2(2):106-15. [In Spanish]

[24] Blanco-Ulate B, Saborío A, Garro-Monge G. Descripción anatómica, propiedades medicinales y uso potencial de Plantago major (llantén mayor). Rev Tecnol Marcha 2008; 21(2):17-24.

[25] Tlili H, Marino A, Ginestra G, Cacciola F, Mondello L, Miceli N. Polyphenolic profile, antibacterial activity and brine shrimp toxicity of leaf extracts from six Tunisian spontaneous species. Nat Prod Res 2019; 1-7. https://doi.org/10.1080/14786419.2019.1616725

[26] Freitas AG, Farias ET, Lima MCA, Sousa IA, Ximenes E. Atividade antiestafilocócica do Plantago major L. Rev Bras Farmacogn 2002; 12(1):64-5. https://doi.org/10.1590/So 102-695X2002000300031 [In Portuguese]

[27] Claros PM, Bilbao PR, Damiani EM. Activity anti-Helicobacter pylori of Plantago major, Clinopodium bolivianum, Calendula officinalis and Piper angustifolium by the method of dissemination of disk. Biofarbo 2007; 15(15):37-42.

[28] Villanueva VA, Nakata HM. Medicinal plants: antibacterial effect in vitro de Plantago major L, Erythroxylum novogranatense, Plowman var truxillense and Camellia sinensis on stomatologic importance bacteria. Odontol Sanmarquina 2014; 13(2):21-5.

[29] Pachamango Leiva VI. Efecto antibacteriano in vitro del extracto de Plantago major (llantén) y del perioaid $\mathbb{R}$ 0.12\% sobre Fusobacterium nucleatum ATCC 25586. [Thesis]. Universidad Nacional de Trujillo: Facultad de Estomatología; 2016. [In Spanish]

[30] Borja Valverde, VC. Efecto inhibitorio del extracto de manzanilla (Matricaria Chamomilla), extracto de llantén (Plantágo major 1.) y la combinación del extracto de manzanilla y llantén comparado con la clorhexidina sobre cepa de Porphyromona gingivalis. [Thesis]. Universidad Central del Ecuador: Facultad de Odontología; 2018.

[31] Clinical and Laboratory Standards Institute. Methods for Antimicrobial Susceptibility Testing of Anaerobic Bacteria; Approved Standard - Eighth Edition. CLSI document M11-A8. Wayne, PA: Clinical and Laboratory Standards Institute; 2012. 